There is thus no threat that the European Community will compel the United Kingdom to reduce its excise taxation on alcoholic beverages. Nor was there when your leader appeared on 13 April 1991. I am grateful to be able to put the record straight - and reassure your readership.

LEON GORDON

Customs Union and Indirect Taxation,

Directorate-General,

Commission of the European Communities,

1049 Brussels,

Belgium

1 Dillner L. Alcohol abuse. BM7 1991;302:859-60. (13 April )

2 Amended proposal for a council directive on the approximation of the rates of excise duty on alcoholic beverages and on the alcohol contained in other products. Official fournal of the European Communities No C 1990 Jan 18:12/12. (COM 89)527 final.)

\section{How to pay for expensive drugs}

SIR,-Professor M Orme's editorial presents a balanced view of the merits of various economic strategies for hospitals' and general practitioners' drug prescribing budgets. He failed, however, to highlight one important aspect. Although there is a trend for hospitals to defer prescribing for outpatients, and for some patients on discharge, to general practitioners in order to reduce hospital pharmacy budgets, the overall cost to the NHS will increase if this policy is pursued. The cost of drugs dispensed by hospital pharmacies is, almost without exception, substantially lower than that levied by the "high street" pharmacist, who, understandably, adds a sizeable mark up to the costs to produce a profit.

Professor Orme is right when he says that a national solution should be sought; it should embrace both hospitals and general practitioners and might also include high street pharmacies.

Ealing Hospital,

Middlesex UB1 $3 \mathrm{HW}$

1 Orme M. How to pay for expensive drugs. BMf 1991;303:593-4. (14 September.)

\section{Health of the nation}

SIR,-Professor I B Pless's comments on accident prevention in his response to The Health of the Nation should be noted by politicians, officials in the Department of Health, and all health workers.' What he is asking is for the Department of Health to take a firm lead in accident prevention (injury control in North American terminology). The justification for this is sound. Accidents are the leading cause of death in the early years of life. In the United States they account for a greater proportion of years of potential life lost than cancer and heart disease combined. They cause much suffering and hardship. They lose the NHS millions of pounds a year.

In supporting Professor Pless's proposals for a division of injury control in the Department of Health I would go even further. I believe that until the discipline is given a similar status to heart disease, cancer, and communicable disease control it will not make any real progress.

For advances to be made an institute (or centre) for accident prevention and injury control attached to an academic institution in the United Kingdom is urgently needed. Such an institute would have a similar role to that of the Communicable Diseases Surveillance Centre. It would act as a clearing house for information on accidents but also collate and stimulate research. It would act as a national focus for action on accidents.

Some will argue that such an institute already exists in the form of the Medical Commission on
Accident Prevention, the Child Accident Prevention Trust, and the Parliamentary Advisory Council on Transport Safety (PACTS). These important organisations are either too specialised or too restricted within their terms of reference. The Royal Society for the Prevention of Accidents operates on a broader front, especially in education. It has already taken a considerable initiative towards working more closely with health authorities with the production of its report Action on Accidents in conjunction with the National Association of Health Authorities and Trusts. ${ }^{2}$ Despite all this activity the need for a national institute still exists.

Several regional and district health authorities have now developed strategies and plans for accident prevention. They cannot go it alone. The government must play its part. As no other agency is likely to take the lead the Department of Health should seize the initiative, recognise its key role, and put substantial resources into making appreciable inroads into this major modern epidemic.

Flecknoe,

JAMES GORDON AVERY

Near Rugby,

Warwickshire CV23 8AT

1 Pless IB. Accident prevention. BMf 1991;303:462-4.

2 National Association of Health Authorities and Royal Society for the Prevention of Accidents Strategy Group. Report. Action on accidents: the unique role of the health service. Birmingham: NAHA, 1990.

SIR,-Drs Martin Dennis and Charles Warlow's proposed strategy for stroke ${ }^{1}$ in response to The Health of the Nation ignores the potentially large contribution of oestrogen replacement treatment in preventing stroke in postmenopausal women: it is estimated to reduce the relative risk by about half in this group. ${ }^{2}$ Reductions in the relative risks of killing or disabling diseases that have been reported in controlled studies of oestrogen replacement treatment with or without balancing progestogens include for strokes $0 \cdot 53,{ }^{2}$ myocardial infarction $0 \cdot 30,{ }^{3}$ and hip fracture $0 \cdot 33 .{ }^{4}$ Additionally, there are significant reductions in other fractures related to osteoporosis. ${ }^{56}$

These observations are supported by a decreased mortality in women using oestrogen replacement treatment. ${ }^{7}$ In the absence of circulating oestrogens there is a threefold to fourfold increase in atherosclerosis in postmenopausal women. ${ }^{8} \mathrm{~W}$ ith one exception, ${ }^{9}$ these figures for the reduction of relative risks have been confirmed to various degrees by other studies.

Oestrogen replacement treatment should be considered in calculations of strategies for decreasing the risk of stroke and improving the health of the nation.

Chairman,

ALLAN ST J DIXON

National Osteoporosis Society,

PO Box 10

Radstock,

Bath BA3 3YB

1 Dennis M, Warlow C. Strategy for stroke. BMJ 1991;303:636-8 (14 September.)

2 Paganini-Hill A, Ross RK, Henderson BE. Postmenopausal oestrogen treatment and stroke: a prospective study. $B M J$ 1988:297:519-22

3 Stampfer MJ, Willet WC, Colditz GA, Rosner B, Speizer FE, Hennekens CA. A prospective study of estrogen therapy and coronary heart disease. N Engl F Med 1985;313:1044-9.

4 Kiel DP, Felson DT, Anderson JJ, Wilson PW, Moskewitz MA Hip fractures and the use of estrogens in postmenopausal Hip fractures and the use of estrogens in postmenopausal
women, the Framingham study. $N$ Engl f Med 1987;317: women,

5 Lindsay R, Hart DM, Forrest C, Baird C. Prevention of spinal osteoporosis in oophorectomised women. Lancet 1980;ii: osteopor.

6 Hutchinson TA, Polansky SM, Feinstein AR. Postmenopausal oestrogens protect against fractures of hip and distal radius, case control study. Lancet 1979; ii:705-9.

7 Henderson BE, Paganini-Hill A, Ross RK. Decreased mortalit in users of estrogen replacement therapy. Arch Intern Med 1991;151:75-8.

8 Witteman JCM, Grobbee DE, Kok FJ, Hofman A, Valkenburg $\mathrm{HA}$. Increased risk of atherosclerosis in women after the menopause. BMF 1989;289:642-4.
9 Wilson PWF, Garrison RJ, Castelli WP. Postmenopausal estrogen use, cigarette smoking and cardiovascular morbidity in women over 50. N Engl f Med 1985;313:1038-43.

\section{Consultants in communicable disease control}

SIR, - Dr G J Duckworth's editorial highlighted the lack of resources, power, and training attached to the newly established posts of consultant in communicable disease control.' ${ }^{\text {Th }}$ This will strike a chord with all junior doctors considering or currently training for this specialty.

Junior doctors head for specialties for many reasons, including interest, the availability of consultant posts, convenience (including the availability of part time work), and possibilities for career progression. A clear career pathway is needed from the various entry routes of public health medicine, microbiology, and infectious disease. Also needed is a description of what promotional possibilities exist-for example, to director of public health or regional epidemiologist. Projections of the future availability of consultant posts could do much to attract high calibre junior doctors to the specialty. A commitment to continuing education for those appointed is required In addition, as new consultants in communicable disease continue to choose a part time commitment the Joint Committee on Higher Medical Training should make it easier to obtain accreditation in joint specialties.

A steering group on training for consultants in communicable disease control is currently examining these and other issues. This group includes representatives from the major connected medical specialties and junior doctors.

Dr Duckworth's assertion that aspects of environmental health are not within the remit of consultants in communicable disease control is not universally shared. Many doctors consider that these important issues are, or should be, within the remit of public health. The public certainly considers that someone should be in charge. The debate is by no means settled.

People are made uncomfortable by change. The Chinese ideogram for change has two parts: "danger" and "opportunity." We should not lose sight of the opportunities for marching boldly forward while we are temporarily stuck in the dangerous and uncertain mire of limited resources. Otherwise consultants in communicable disease control will find themselves in a career cul de sac.

Department of Public Health Medicine,

MARY E BLACK

Eastern Health and Sochealth Medicine,

Belfast BT2 8BS

1 Duckworth GJ. Consultants in communicable disease control. $B M \mathcal{F} 1$ 1991;303:483-4. (31 August.)

SIR,-All health authorities are now busy with purchasing and contracting just as in 1974 they were busy with information and planning. In such a situation control of communicable disease may be considered to be unimportant. I find, however, that Dr G J Duckworth failed to mention in his editorial' the role of the consultant in communicable disease control regarding the childhood vaccination and immunisation programme and the control programme for HIV infection and AIDS. In many districts the immunisation coordinator is the consultant in communicable disease control, who also has executive responsibility for HIV infection and AIDS. In some districts this is not the case. This situation therefore requires rectification for obvious reasons and was referred to in the report Public Health in England. ${ }^{2}$

Dr Duckworth also speaks of "financial autonomy" to match but does not indicate how this should be brought about. My proposal is for a communicable disease control unit headed by the 